\title{
NOTE
}

\section{Fragilidium cf. mexicanum, a thecate mixotrophic dinoflagellate which is prey for and a predator on co-occurring thecate heterotrophic dinoflagellate Protoperidinium cf. divergens}

\author{
Hae Jin Jeong *, Chang Won Lee, Won Ho Yih, Jae Seong Kim
}

Department of Oceanography, College of Natural Sciences, Kunsan National University, Kunsan 573-701, Korea

\begin{abstract}
The thecate heterotrophic dinoflagellate Protoperidinium cf. divergens and the thecate mixotrophic dinoflagellate Fragilidium of. mexicanum feed on each other In general, $F$. cf. mexicanum is the predominant predator in this reciprocal predation. At initial concentration ratios $\leq 0.4$ (F. cf. mexicanum: $P$. cf. divergens), both species fed on each other, but did not seriously affect the other's population. At ratios $\geq 0.8$, $P$. cf. divergens was drastically reduced to very low concentrations, and uctive predation by $F$. cf. mexicanum on $P$. cf. divergens was observed. This reciprocal predation may affect our view of energy and cycling of carbon in the planktonic community
\end{abstract}

KEY WORDS: Dinoflagellate Food web - Heterotrophy Mixotrophy Protist Reciprocal predation

Interest in mixotrophic and heterotrophic dinoflagellates has recently increased because of their diverse roles in marine food webs (Hansen 1992, Bockstahler \& Coats 1993, Jeong 1994a, b, Jeong \& Latz 1994). Several dinoflagellates previously thought to be autotrophic have been found to be heterotrophic or mixotrophic (Gaines \& Taylor 1984, Bockstahler \& Coats 1993, Jacobson \& Anderson 1996, Li et al. 1996).

Species in the genus Fragilidium have been reported in the coastal waters of many areas (Balech \& Ferrando 1964, Eppley \& Harrison 1975, Steidinger \& Tangen 1996). Fragilidium has chloroplasts and some species have been known to be phagotrophic as well (Balech \& Ferrando 1964, Steidinger \& Tangen 1996). Fragilidium may have a strong prey preference; F. subglobosum fed exclusively on Ceratium spp. when offered diverse dinoflagellate and diatom prey (Skovgaard 1996), and $F$. heterolobum was observed to feed on Gonyaulax polyedra (Balech \& Ferrando 1964). However, no studies have considered Fragilidium feeding

·E-mail: hjjeong@ks.kunsan.ac.kr on heterotrophic organisms or the predators on Fragilidium.

Species in the genus Protoperidinium are heterotrophic dinoflagellates ubiquitous in the world's oceans (Lessard 1984, Hansen 1991b, Stoecker et al. 1993). They are often particularly abundant during red tides of dinoflagellates (Allen 1949, Legovic et al. 1991. Jeong 1995), or during diatom blooms (Jacobson 1987). Several studies (Allen 1949, Paasche \& Kristiansen 1982, Dale \& Dahl 1987, Jacobson 1987) reported abundances $\geq 20$ Protoperidinium $\mathrm{ml}^{-1}$

Protoperidinium play diverse roles in marine food webs; they are predators of diatoms (Hansen 1992, Jacobson \& Anderson 1993, Buskey et al. 1994) and red-tide dinoflagellates (Jacobson \& Anderson 1986. Hansen 1991b, Jeong \& Latz 1994). They are not only important prey for copepods, but also predators on copepod eggs and early naupliar stages (Jeong 1994a, b). Jeong \& Latz (1994) showed that some species of Protoperidinium grew well on some southern Californian red-tide dinoflagellates in laboratory cultures, and suggested that Protoperidinium might have a considerable grazing impact on prey populations.

We have observed Protoperidinium cf. divergens (Ehrenberg) Balech predation on a Fragilidium cf. mexicanum Balech cell, while other F. cf. mexicanum in the culture fed on other Protoperidinium cells. Therefore, F. cf. mexicanum is prey for and a predator on Protoperidinium. The present study provides a basis for understanding interactions between $P$. cf. divergens (a thecate heterotrophic dinoflagellate) and cooccurring $F$. cf. mexicanum (a thecate mixotrophic dinoflagellate), and relevant trophodynamics.

Materials and methods. Isolation and culture of dinoflagellates: Plankton samples were taken at the end of the Scripps pier (La Jolla, California, USA) during May 1996 using a $35 \mathrm{~cm}$ diameter, $25 \mu \mathrm{m}$ mesh 
plankton net, and then screened gently through $101 \mu \mathrm{m}$ Nitex mesh, placed in $150 \mathrm{ml}$ plastic bottles, and sent to Korea. These samples were transferred to $270 \mathrm{ml}$ polycarbonate (PC) bottles. Gonyaulax polyedra Stein was added along with $50 \mathrm{ml}$ of BWM medium (Brand 1986). Bottles were placed on wheels rotating at $0.9 \mathrm{rpm}$ under a $12: 12 \mathrm{~h}$ light-dark cycle with $50 \mu \mathrm{E}$ $\mathrm{m}^{-2} \mathrm{~s}^{-1}$ of cool white fluorescent light at $22 \pm 1^{\circ} \mathrm{C}$. Every 2 or $3 \mathrm{~d}$, aliquots of the enriched water were transferred to new PC bottles containing freshly filtered seawater and $G$. polyedra to increase the populations of grazers. Protoperidinium of. divergens and Fragilidium cf. mexicanum became abundant.

Taxonomic authorities used to identify Fragilidium cf. mexicanum were Balech $(1959,1988,1990)$ and von Stosch (1969). For identification, its plate patterns and thecate forms were examined with a Jeol JSM5410 scanning electron microscope (Fig 1). The closest species is F mexicanum. Plate 1" has 4 angles, a slot, and a pore (sometimes not completely perforated, but deeply dented), which are clearly different from $F$. heterolobum and F. fissile. Plate $1^{\prime \prime}$ is a narrow trapezoid with a length-to-width ratio of 2.2 . Plate $7^{\prime \prime \prime}$ is trapezoidal, wider behind, and obviously different from that of F. subglobosum.

Individual Fragilidium cf. mexicanum from the enriched water were transferred to wells of a 24 -well plate (1. cell per well) containing BWM medium, freshly filtered seawater, and Gonyaulax polyedra which was found to support rapid growth of $F$. cf. mexicanum (Jeong unpubl. data) The multi-well plate was placed on a shelf under continuous illumination with $50 \mu \mathrm{E} \mathrm{m} \mathrm{m}^{-2} \mathrm{~s}^{-1}$ of cool white fluorescent light at $22 \pm 1^{\circ} \mathrm{C}$, and observed daily under a dissecting microscope to examine the condition of $F$. cf. mexicanum. When 1 cell grew to approximately 30 cells in a well, these were distributed into wells of new 24 -well plates containing BWM media, freshly filtered seawater, and $G$. polyedra. Two healthy strains of $F$. cf. mexicanum have been established, and one of them was used for these experiments. Once dense cultures of $F$ cf. mexicanum were obtained, they were transferred to bottles of tresh prey every $2 \mathrm{~d}$. To accomplish this, cultures were sieved though $80 \mu \mathrm{m}$ mesh to remove detritus and then screened through $45 \mu \mathrm{m}$ mesh to retain the large cells. Large cells were then transferred to 500 or $1000 \mathrm{ml} \mathrm{PC}$ bottles containing freshly filtered seawater and $G$. polyedra. Most $F$. cf. mexicanum recovered their normal swimming ability within $1 \mathrm{~h}$ of being sieved. When a large volume of $F$. cf. mexicanum culture was available, experiments were conducted.

Details of culturing Protoperidinium of. divergens are described by Jeong \& Latz (1994).

Feeding process: To observe the feeding process, dense cultures of Protoperidinium cf. divergens and
A

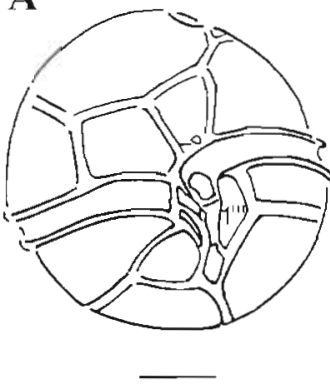

B

C

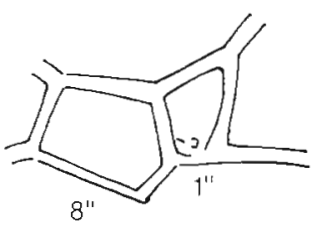

D

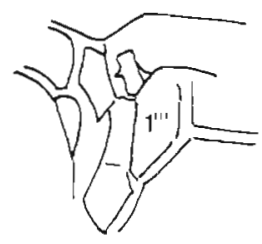

$\mathrm{E}$

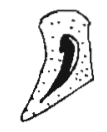

Fig. 1. Fragilidum cf. mexicanum. $(A, B)$ Ventral view. (C) 1' (with a slot and a porel and 8" plates (D) Sulcal plates. (E) Apical pore plate. Scale bars $=10 \mu \mathrm{m}$

Fragilidium cf. mexicanum were transferred to $85 \mathrm{ml}$ $\mathrm{PC}$ bottles. Bottles were placed on rotating wheels at $0.9 \mathrm{rpm}$ under dim light at $22^{\circ} \mathrm{C}$ for 1 to $8 \mathrm{~h}$. Contents were then gently transferred to 6 -well plates. $P$ cf divergens cells with a pallium containing several stages of the feeding process and $F$. cf. mexicanum cells containing 1 or more $P$. cf. divergens cells were very carefully transferred by a Pasteur micropipette into Sedgwick-Rafter counting chambers, and then pictures were taken using an Olympus camera on a compound microscope at a magnification of 40 to $400 \times$.

The feeding process of Fragilidium cf. mexicanum on Protoperidinium cf. divergens was also recorded with a video camera system on an Olympus compound microscope and dissecting microscope at a magnification of 10 to $100 x$

Effects of reciprocal predation: Two experiments were designed to investigate the effects of the reciprocal predation when Fragilidium of mexicanum and Protoperidinium cf. divergens were mixed. The initial concentrations (cells $\mathrm{ml}^{-1}$ ) of $F$ cf. mexicanum and $P$. cf. divergens (and corresponding ratios of $F$. cf. mexicanum to P. cf. divergens) were $5.9 .65(0.09), 11.4: 63.4$ $(0.18), 27.6: 65.3(0.42), 54.2: 62(0.87)$, and $112: 63.5$ (1.76) in Expt 1 and 36:39 (0.92) in Expt 2. 
More than $2 \mathrm{wk}$ before these experiments were set up, cultures of Fragilidium cf. mexicanum or Protoperidinium cf divergens were transferred every $2 d$ into new bottles containing freshly filtered seawater and Gonyaulax polyedra. Dense populations of both grazers actively fed on and eliminated most $G$. polyedra within $2 \mathrm{~d}$ and appeared very healthy. When $G$. polyedra concentrations became low, dense cultures were sieved though $45 \mu \mathrm{m}$ mesh; the retained large cells of each species were transferred to $1000 \mathrm{ml}$ PC bottles. The bottles containing very dense populations of $F$. cf. mexicanum or $P$. cf. divergens with low concentrations of large $G$. polyedra cells were filled to capacity with filtered seawater and placed on rotating wheels at $0.9 \mathrm{rpm}$ under very dim light $\left(1 \mu \mathrm{E} \mathrm{m}^{-2} \mathrm{~s}^{-1}\right)$ at $22^{\circ} \mathrm{C}$ to acclimate for approximately 11 and $7 \mathrm{~h}$ in Expts 1 and 2 , respectively. Bottles taken from the rotating wheel at intervals were observed under a dissecting microscope to examine the conditions of $F$. cf. mexicanum and $P$. cf. divergens and the presence of $G$. polyedra and then placed back onto the rotating wheels. Most $F$ cf. mexicanum and $P$. cf divergens cells which had been sieved recovered their normal swimming ability within 1 h. G. polyedra completely disappeared within approximately 6 and 4 h in Expts 1 and 2, respectively. Three $1 \mathrm{ml}$ aliquots of $F$. of mexicanum or $P$. cf divergens from the bottles were counted to determine their concentrations under a compound microscope.

In Expts 1 and 2, the initial concentrations of Fragilidium of mexicanum or Protoperidinium of divergens were established using an autopipette to deliver known cell concentrations to the bottles. Triplicate $270 \mathrm{ml}$ experiment bottles (mixtures of both species) were set up at all concentration combinations. One set of triplicate control bottles contained only $P$. cf, divergens. The other set of triplicate control bottles containing only $F$. cf. mexicanum were initially set up at all $F$. cf. mexicanum concentrations. Experimental and control bottles were placed on rotating wheels at $0.9 \mathrm{rpm}$ under continuous dim light $\left(1 \mu \mathrm{E} \mathrm{m}^{-2} \mathrm{~s}^{-1}\right)$ at $22^{\circ} \mathrm{C}$ for 64 and $52 \mathrm{~h}$ in Expts 1 and 2, respectively. We incubated bottles under dim light to prevent the possible phototrophic growth of $F$. cf. mexicanum. The maximum growth rate of $F$. cf. mexicanum without added. prey under continuous illumination $\left(130 \mu \mathrm{E} \mathrm{m}^{-2} \mathrm{~s}^{-1}\right)$ at $22^{\circ} \mathrm{C}$ was approximately $0.3 \mathrm{~d}^{-1}$ (Jeong unpubl. data). Ten $\mathrm{ml}$ aliquots, taken from all bottles at intervals, were fixed with acidic Lugol's solution. In Expt 1, at 18,37 , and $63 \mathrm{~h}$, and in Expt 2, at $6 \mathrm{~h}$, the contents inside all experimental bottles and 1 control bottle at each concentration wert carefully observed looking through the surface of the bottles without removing the cap) under a dissecting microscope to examine the interactions and condition of F. cf. mexicanum and/or $P$. cf divergens. After subsamples were taken, bottles were filled again to capacity with freshly filtered seawater using a micropipette and placed back on rotating wheels. The concentrations of $F$. cf. mexicanum or $P$. cf. divergens were determined by counting all cells in five $1 \mathrm{ml}$ Sedgwick-Rafter counting chambers under a compound microscope.

Results. Feeding process: Fragilidium cf. mexicanum can engulf Protoperidinium of divergens cells of similar cell size (Fig. 2A) Within 2 h F. cf. mexicanum digested more than one-third of a $P$. cf. divergens cell and engulfed a new $P$. of divergens cell (Fig 2B, C, D). This can be easily detected because the cell surface of $F$. of mexicanum is almost transparent The shape of $F$. cf. mexicanum containing 1 or more $P$ cf. divergens cells was diverse; round, oval, quadrilateral, and sometimes amorphous (Fig 2A, B, C, D) Their sizes were usually $>70 \mu \mathrm{m}$ and sometimes reached $100 \mu \mathrm{m}$. This large size and shape allowed quick and unambiguous detection of $F$ cf. mexicanum cells containing $P$ cf. divergens at a glance under a dissecting microscope.

Protoperidinium cf. divergens fed on Fragilidium of mexicanum by means of a pallium (Fig 2E, F). Sometimes more than $6 P$. cf. divergens cells could be seen simultaneously attacking a $F$. cf. mexicanum cell, as has been observed when feeding on a copepod egg and nauplius (Jeong 1994b). The pallium containing the fecal aggregations was conspicuous because it was large (similar to the cell size of $P$. cf. divergens) and did not shrink for some time.

Effects of reciprocal predation: In Expt 1, both species fed on each other at low ratios of the initial concentrations (Fragilidium cf. mexicanum: Protoperidinium cf. divergens $\leq 0.4$ ), but the presence of the reciprocal predators did not markedly affect the other's population (Fig. 3A, B, C). However, at higher ratios $(\geq 0.8)$, the concentrations of $P$. cf. divergens in experimental bottles was markedly lower than those in control bottles (Fig. 3D, E). At the ratio of 1.8, P. cf, divergens concentrations in experimental bottles drastically decreased to 3 cells $\mathrm{ml}^{-1}(5 \%$ of the initial concentration) at $64 \mathrm{~h}$. Similar rapid decrease in $P$. cf. divergens concentrations was also found in Expt 2 (ratio of 0.9 ; Fig. 4). However, the feeding by $F$ cf. mexicanum on $P$. cf divergens did not support the growth of $F$. cf. mexicanum. In Expt 2 F. cf. mexicanum in experimental bottles maintained its population constant from 29 to $52 \mathrm{~h}$ after the $P$. cf. divergens concentration drastically declined from 0 to $29 \mathrm{~h}$, while the $F$. cf. mexicanum concentration in control bottles continuously decreased. Energy gained from the predation on $P$. cf. divergens from 0 to $29 \mathrm{~h}$ might have enabled $F$. cf. mexicanum to maintain a constant population.

It was observed under a dissecting microscope that the feeding by Protoperidinium of divergens on Fragi- 

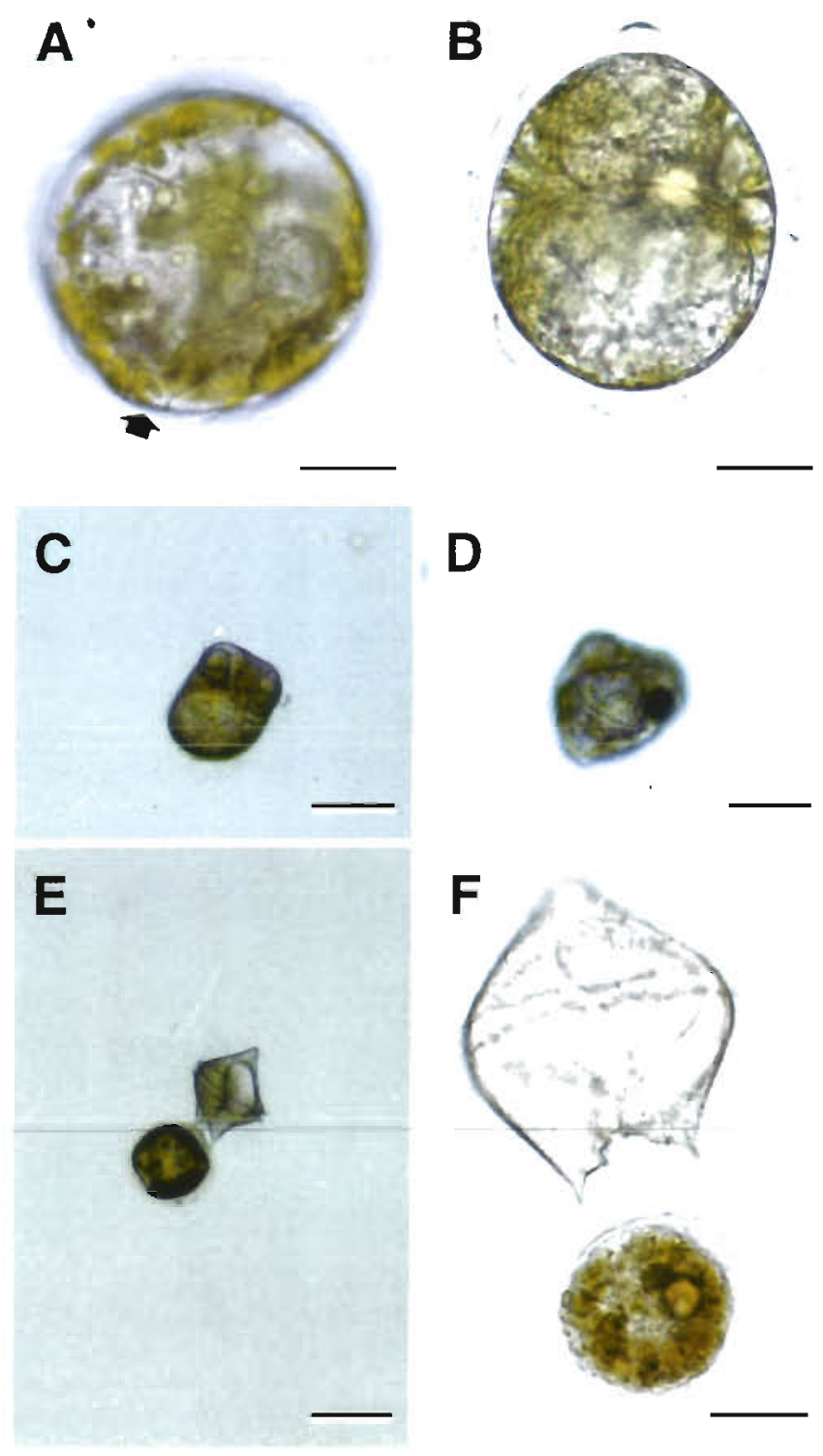

Fig. 2. Fragilidium cf. mexicanum. Shape when feeding on Protoperidinium of divergens (and numbers of prey inside the protoplasm of the predator). (A) Round (1 P. cf. divergens cell: antapical horns, arrowhead). (B) Oval (1 cell semidigested and 1 newly ingested). (C) Quadrilateral (2 almost digested and 1 newly ingested cells). (D) Amorphorous (3 almost digested and 1 newly ingested cells). P. cf. divergens feeding on an F. cf. mexicanum cell. (E) Attached pallium containing an $F$. cf. mexicanum cell. (F) Detached pallium after feeding was interrupted. $F$, cf. mexicanum and $P$. cf. divergens cells were not the same ones as in A to F Scale bar $=20 \mu \mathrm{m}$ in $\mathrm{A}, \mathrm{B}$, and $\mathrm{F}$ and $60 \mu \mathrm{m}$ in $\mathrm{C}, \mathrm{D}$, and $\mathrm{E}$

lidium of mexicanum occurred at all ratios, but especially at the ratios of $0.2,0.4$, and 0.8 . The feeding by $F$. cf. mexicanum on $P$ cf. divergens was observed at all ratios except 0.09 , but was most marked at ratios of 0.8 and 1.8 in Expt 1. Many large $F$. cf. mexicanum
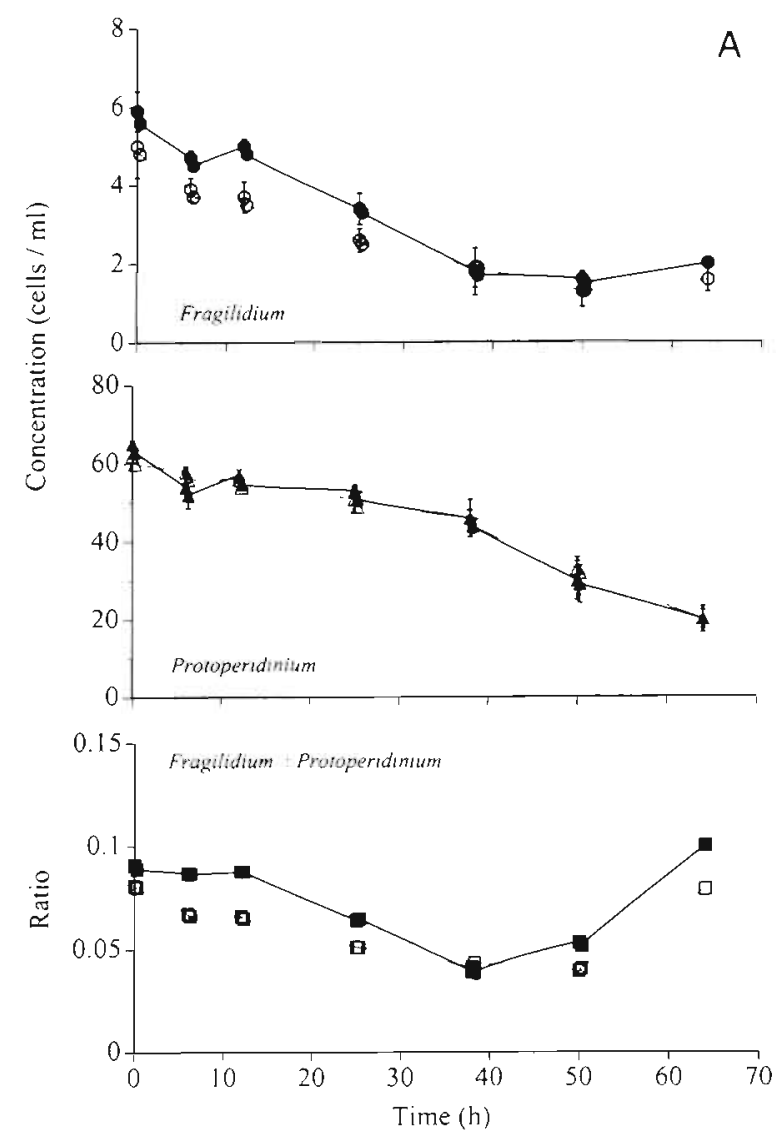

Fig. 3. Fragilidium of mexicanum and Protoperidinium of divergens. Concentrations and ratios ( $F$. cf. mexicanum $P$. cf. divergens) as a function of incubation time (Expt 1). Initial concentrations (cells $\mathrm{ml}^{-1}$ ) of $F$. cf. mexicanum and $P$. cf divergens (and corresponding ratios of $F$. cf. mexicanum to $P$. cf. divergens) are (A) 5.9:65 (0.09), (B) 11.4:63.4 (0.18), (C) $27.6: 65.3(0.42)$, (D) $54.2: 62(0.87)$, (E) 112.63 .5 (1.76) Symbols represent treatment means $\pm 1 \mathrm{SE}$. ( Experimental bottles containing $F$. cf. mexicanum and ( $\mathbf{\Delta}) P$. cf. divergens and ( ) their ratios. (O) Control bottles containing only $F$. cf. mexicanum or $(\Delta)$ only $P$. cf. divergens and $(\square)$ their ratios

cells were observed to contain a $P$. cf. divergens cell at $6 \mathrm{~h}$ in Expt 2.

The evidence from feeding experiments and microscopic examination suggests that Fragilidium cf. mexicanum may have a considerable predation impact on the population of Protoperidinium of divergens when the ratio of the initial concentrations ( $F$. cf. mexicanum: P. cf. divergens) is greater than 0.8 .

Discussion. The present study shows that Fragilldium cf. mexicanum and Protoperidinium cf. divergens can prey on each other. However, at ratios of the initial concentrations $\geq 0.8$ ( $F$. cf. mexicanum $P$. cf. divergens), $F$. cf. mexicanum fed on $P$. cf. divergens more than $P$. cf. divergens fed on $F$. cf. mexicanum, and $F$. cf. 

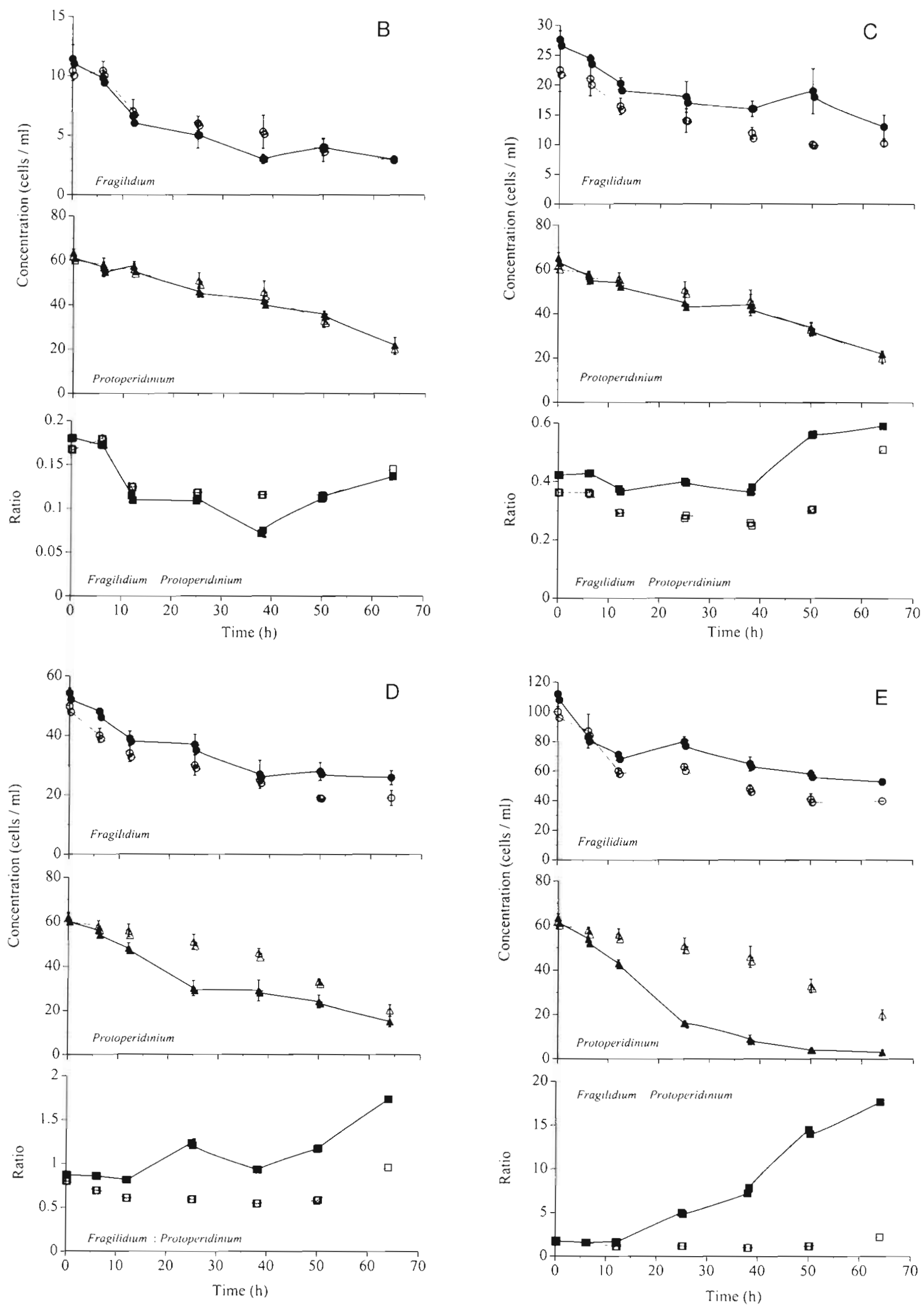


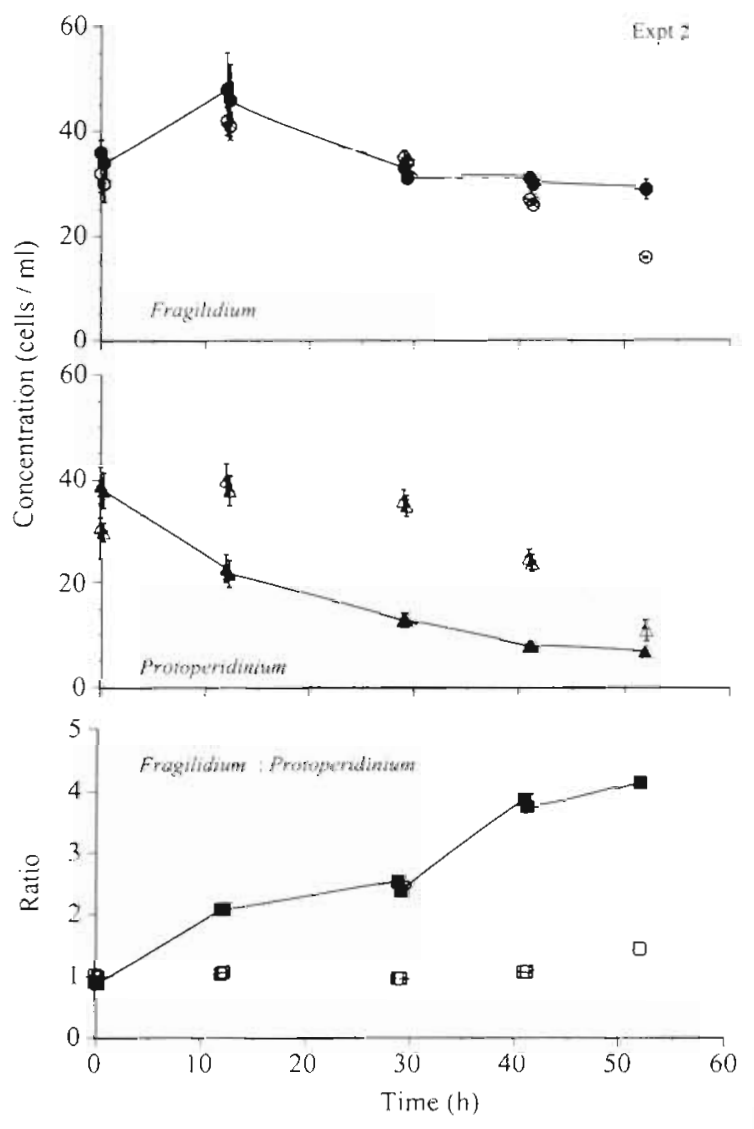

Fig. 4. Fragilidium cf. mexicanum and Protoperidinium of. divergens. Concentrations and ratios $(F$. cf. mexicanum: $P$. cf. divergens) as a function of incubation time (Expt 2). Initial concentration (cells $\mathrm{ml}^{-1}$ ) of $F$. of. mexicanum and $P$. cf. divergens land corresponding ratios of $F$. cf. mexicanum to $P$. cf. divergens) was $36: 39$ (0.92). Symbols represent treatment means $\pm 1 \mathrm{SE}$. Symbols as in Fig. 3

mexicanum had a considerable predation impact on the population of $P$. cf. divergens. This reciprocal predation may be important in planktonic communities in the following ways: (1) F. cf. mexicanum can survive at low light intensity and nutrient conditions by feeding on $P$. cf. divergens, and possibly other heterotrophic protists. (2) Carbon would be quickly recycled between the populations of $F$ cf. mexicanum and $P$. cf divergens. (3) The predator-prey relationship can be reversed any time. (4) The grazing impact by Protoperidinium populations on preferred red-tide dinoflagellate prey can be reduced if $F$. cf. mexicanum cooccurs.

Reversals of prey-predator relationships have also been observed between Protoperidinium cf divergens and copepods, and between the dinoflagellate genus Dinophysis and the ciliate Tiarina fusus. P. cf. divergens, prey for adult copepods, itself feeds on copenod eggs and early naupliar stages (Jeong 1994b). T fusus is a predator of autotrophic Dinophysis spp., but prey for heterotrophic Dinophysis spp. (Hansen 1991a). However, there have been few reports of direct reversal of the prey-predator relationship in marine planktonic communities.

Toxicity of Fragilidium cf. mexicanum has not been studied, but it is unlikel: that there were toxic effects of F. cf. mexicanum on Protoperidinium of divergens. When the ratios of $F$. cf. mexicanum to $P$. cf divergens were similar (0.87 in. Fig. 3D and 0.92 in Fig 4), the reduction in the population of $P$. cf divergens (difference in reductions between experimental and control bottles: $53.2 \%-25.8 \%=27.4 \%$ ) at the higher concentration of F. cf. mexicanum (54.2 cells ml ${ }^{-1}$; Fig. 3D) for the first $40 \mathrm{~h}$ was rather smaller than that $179.5 \%$ $19.4 \%=60.1 \%$ ) at the lower concentration (36 cells $\mathrm{ml}^{-1}$; Fig. 4).

To understand further the interactions between Protoperidinium and Fragilidium populations, it would be worth while to explore the distributions and population dynamics of Protoperidinium and Fragilidium, and effects of the presence of alternative prey during and/or after red tides dominated by common prey le.g. Gonyaulax polyedra, and possibly Alexandrium tamarense, Scrippsiella trochoidea etc.) when both groups are abundant.

Acknowledgements. We thank Michael Mullin, Peter Franks, and Per Juel Hansen for comments on the manuscript. We also thank Michael Latz for collecting and sending water samples, and Man Cheol Kim and Jae Yeun Park for technical support. This paper was funded by a grant from Ministry of Agriculture, Forestry, and Fisheries, Korean Government.

\section{LITERATURE CITED}

Allen WE (1949) Data files, 1917-1949. Accession No. 81-19. Scripps Institution of Oceanography Archives, Unıversity of California, San Diego

Balech E (1959) Two new genera of dinoflagellates from California. Biol Bull 166:195-203

Balech E (1988) Una especie nueva del género Fragilidium (Dinoflagellata) de la Bahía de Chamela, Jalisco, Mexico. An Inst Biol Univ Nac Auton Mex Ser Zool 58:479-486

Balech E (1990) Four new dinoflagellates. Helgol Meeresunters 44:387-396

Balech E, Ferrando HJ (1964) Fitoplancton marino. Editorial Univ Buenos Aires

Bockstahler KR, Coats DW (1993) Spatial and temporal aspects of mixotrophy in Chesapeake Bay dinoflagellates. J Eukaryot Microbiol 40:49-60

Brand LE. (1986) Nutrition and culture of autotrophic ultraplankton and picoplankton. Can Bull Fish Aquat Sci 214 205-233

Buskey EJ, Coulter CJ, Brown SL (1994) Feeding, growth and bioluminescence of the heterotrophic dinoflagellate Protoperidinium huberi. Mar Biol 121:373-380

Dale T. Dah! E (1987) Mass occurrence of planktonic oligotrnchous ciliates in a bay in southern Norway. J Plankton Res 9:871-879 
Eppley RW, Harrison WG (1975) Physiological ecology of Gonyaulax polyedra, a red tide water dinoflagellate of southern California. In: Locicero VR (ed) Proceedings First International Conference on Toxic Dinoflagellate Blooms. Massachusetts Science and Technology Foundation, Wakefield, MA; p 11-22

Gaines G, Taylor FJR (1984) Extracellular digestion in marine dinoflagellates. J Plankton Res 6:1057-1061

Hansen PJ (1991a) Dinophysis-a planktonıc dınoflagellate genus which can act both as a prey and a predator of a ciliate. Mar Ecol Prog Ser 69:201-204

Hansen PJ (1991b) Quantitative importance and trophical role of heterotrophic dinoflagellates in a coastal pelagral food web. Mar Ecol Prog Ser 73:253-261

Hansen PJ (1992) Prey size selection, feeding rates and growth dynamics of heterotrophic dinoflagellates with special emphasis on Gyrodinium spirale. Mar Biol 114: $327-334$

Jacobson DM (1987) The ecology and feeding biology of thecate heterotrophic dinoflagellates. PhD thesss, Woods Hole Oceanographic Institution/Massachusetts Institute of Technology Joint Program

Jacobson DM. Anderson DM (1986) Thecate heterotrophic dinoflagellates: feeding behavior and mechanisms. J Phycol 22:249-258

Jacobson DM, Anderson DM (1993) Growth and grazing rates of Protoperidinium hirobis Abé, a thecate heterotrophic dinofiagellate. J Plankton Res 15:723-736

Jacobson DM, Anderson DM (1996) Widespread phagocytosis of ciliates and other protists by marine mixotrophic and heterotrophic thecate dinoflagellates. J Phycol 32:279-285

Jeong HJ (1994a) Predation effects of the calanoid copepod Acartia tonsa on a population of the heterotrophic dinoflagellate, Protoperidinium, in the presence of co-occurring red-tide dinoflagellate prey. Mar Ecol Prog Ser 111:87-97

This note was presented by D. K. Stoecker (Senior Editorial Advisor), Cambridge, Maryland, USA
Jeong $H J$ (1994b) Predation by the heterotrophic dinoflagellate Protoperidinum cf. divergens on copepod eggs and early naupliar stages. Mar Ecol Prog Ser 114:203-208

Jeong HJ (1995) The interactions between microzooplanktonic grazers and dinoflagellates causing red tides in the open coastal waters off southern California. PhD thesis. Unuversity of California, San Diego

Jeong HJ, Latz Ml (1994) Growth and grazing rates of the heterotrophic dinoflagellate, Protopendinium, on sed tide dinoflagellates. Mar Ecol Prog Ser 106:173-185

Legovic T, Vilicic D, Petricoli D, Zutic V (1991) Subsurface Gonyaulax polyedra bloom in a stratified estuary. Mar Chem 32:361-374

Lessard EJ (1984) Oceanic heterotrophic dinoflagellates: distribution, abundance and role as microzooplankton. PhD thesı, University of Rhode Island

Li A, Stoecker DK, Coats DW, Adam EJ (1996) Ingestion of fluorescently labeled and phycoerythrin-containing prey by mixotrophic dinoflagellates. Aquat Microb Ecol 10 : $139-147$

Paasche E, Knstlansen S (1982) Ammonium regeneration by microzooplankton in the Oslofjord. Mar Bıol 69:55-63

Skovgaard A (1996) Engulfment of Ceratium spp. (Dinophyceae) by the thecate photosynthetic dinoflagellate Fragilidium subglobosum. Phycologia 35:490-499

Steidinger KA, Tangen K (1996) Dinoflagellates. In: Tomas $C R$ (ed) Identifying marine diatom and dinoflagellates. Academic Press, San Diego, p 387-584

Stoecker DK. Buck KR, Putt M (1993) Changes in the sea-ıce brine community during the spring-summer transition, McMurdo Sound, Antarctica. II. Phagotrophic protısts. Mar Ecol Prog Ser 95:103-113

Von Stosch HA 11969) Dinoflagellaten aus der Nordsee Il. Helgolandinium subglobosum gen. et spec. nov. Helgol Wiss Meeresunters 19:569-577

Manuscupt first recelved: September 25, 1996

Revised version accepted: March 4, 1997 